\title{
FENOMENA PENGHINDARAN PAJAK DI PERUSAHAAN INDUSTRI DASAR DAN KIMIA
}

\author{
Yona Dwi Yuniar ${ }^{1}$, Ari Kamayanti ${ }^{2}$, Andi Asdani ${ }^{3}$ \\ Politeknik Negeri Malang, Malang, Indonesia \\ Email korespondensi: ${ }^{1}$ yona22.yuniar@gmail.com
}

\begin{abstract}
ABSTRAK
Penelitian ini bertujuan untuk menganalisis pengaruh manajemen laba akrual, leverage, good corporate governance terhadap penghindaran pajak pada perusahaan sektor industri dasar dan kimia. Populasi penelitian ini adalah seluruh perusahaan sektor industri dasar dan kimia yang terdaftar di Bursa EFek Indonesia periode 2015-2019. Sampel penelitian dipilih dengan metode purposive sampling dan diperoleh sebanyak 12 perusahaan. Analisis data dalam penelitian ini menggunakan analisis regresi berganda. Hasil analisis menunjukkan bahwa manajemen laba, kepemilikan institusional, dan proporsi dewan komisaris independen tidak berpengaruh terhadap penghindaran pajak, sedangkan leverage dan komite audit berpengaruh terhadap perilaku penghindaran pajak. Perusahaan sebaiknya lebih meningkatkan kinerja dewan komisaris khususnya dewan komisaris independen. Perusahaan harus memperhatikan level kompetisi, keahlian, dana pengalaman dari setiap anggota dewan agar terhindar dari tindakan kecurangan khususnya penghindaran pajak diantaranya dengan menambah jumlah dewan komisaris independen yang tidak terafiliasi dengan perusahaan dan memiliki pengetahuan lebih mengenai perpajakan perusahaan serta memiliki tingkat independensi yang tinggi.
\end{abstract}

Kata kunci: good corporate governance; leverage; manajemen laba; penghindaran pajak

\begin{abstract}
This study aims to analyze the effect of accrual earnings management, leverage, good corporate governance on tax avoidance in basic and chemical industry companies. The population of this research are all basic and chemical industrial sector companies listed on the Indonesia Stock Exchange for the period 2015-2019. The research sample was selected by purposive sampling method and obtained as many as 12 companies. Data analysis in this study used multiple regression analysis. The results of the analysis show that earnings management has no effect on tax avoidance, while leverage, institutional ownership, the proportion of independent commissioners, and audit committees affect tax avoidance behavior. The company should further improve the performance of the board of commissioners, especially the independent board of commissioners. Companies must pay attention to the level of competition, expertise, and experience of each member of the board to avoid fraud, especially tax avoidance, including by increasing the number of independent commissioners who are not affiliated with the company and have more knowledge about corporate taxation and have a high level of independence.
\end{abstract}

Keywords: good corporate governance; leverage; profit management; tax evasion

\section{KETERANGAN ARTIKEL}

Riwayat Artikel: diterima: 29 Agustus 2021; direvisi: 17 Desember 2021; disetujui: 24 Desember 2021

Klasifikasi JEL: H26

Cara mensitasi: Yuniar, Y. D., Kamayanti, A., \& Asdani, A. (2021). Fenomena Penghindaran Pajak Pada Perusahaan Industri Dasar Dan Kimia. JIAFE (Jurnal Ilmiah Akuntansi Fakultas Ekonomi, 7(2), $247-258$. https://doi.org/10.34204/jiafe.v7i2.3795 


\section{PENDAHULUAN}

Dari perspektif pajak, perbedaan antara tujuan perusahaan dan pemerintah adalah berusaha merasionalisasi beban pajak mereka untuk mendapatkan lebih banyak keuntungan untuk kemakmuran investor dan kelangsungan hidup perusahaan, pemerintah mencoba merasionalkan beban pajak mereka sebanyak mungkin (Yoehana, 2013). Perbedaan kepentingan tersebut menghalangi wajib pajak manajeman atau badan untuk melaksanakan tindakan penghindaran pajak. Penghindaran pajak yakni aktivitas legal serta tindakan mengurangi kewajiban pajak yang tidak menentang undang-undang perpajakan. Penghindaran ini, di satu sisi, dapat ditoleransi atau diizinkan, sementara di sisi lain mereka tidak menguntungkan dan karena itu kompleks dan unik (Budiman \& Setiyono, 2012).

Perusahaan yang berorientasi pada laba berupaya untuk memaksimalkan laba melalui efisiensi biaya. Manajemen perusahaan yang teribat dalam penyusuan laporan berusaha untuk mengendalikan laba untuk keperluan pribadi. Manajemen laba merupakan bagian yang digunakan dalam hal memenuhi kewajiban perpajakan secara utuh, akan tetapi dapat meminimalkan pajak terutang untuk menjaga profitabilitas. Salah satu rasio keuangan yang mempengaruhi penghindaran pajak (tax avoidance) adalah leverage. Leverage adalah suatu perbandingan yang menunjukkan jumlah utang yang dipakai perusahaan untuk mendanai aktivitas operasionalnya. Pemakaian utang yang tinggi oleh perusahaan akan diikuti bunga tinggi yang wajib dibayar oleh perusahaan, hal ini dapat mengurangi jumlah laba sebelum pajak dan akan berujung pada berkurangnya pajak yang wajib dibayar perusahaan (Surbakti, 2012). Pada penelitian ini leverage dihitung menggunakan alat analisis debt to equity ratio (DER). Berdasarkan penelitian Dewinta \& Setiawan (2016), leverage dinyatakan memiliki pengaruh negatif pada penghindaran pajak (tax avoidance), sedangkan Marfiah \& Syam (2016) dalam penelitiannya menyatakan bahwa leverage pengaruh positif pada penghindaran pajak.

Selain manajemen laba dan kinerja keuangan, pengelolaan yang baik telah menjadi alat analisis untuk penghindaran pajak. Pengelolaan perusahaan akan memiliki dampak positif apabila memiliki kinerja yang optimal. Komponen good corporate governance (GCG) yang dipakai oleh peneliti adalah kepemilikan institusional, komisaris independen, dan komite audit. Implementasi GCG memiliki dua sistem prosedur, yakni prosedur internal dan eksternal (Fadhilah \& Rahmi, 2014). Prosedur internal GCG salahsatunya untuk menjalankan perusahaan sesuai dengan prosedur dan struktur internal. Sedangkan pada mekanisme penerapan secara ekternal dilakukan upaya pemantauan aktivitas perusahan, pengendalian pasar, dan struktur kepemilikan. Kepemilikan institusional lebih berperan penting dibandingkan kepemilikan manajerial, karena sesuai dengan kondisi di Indonesia. Dengan adanya kepemilikan institusional, pemeriksaan dalam perusahaan yang optimum, seringkali para pemegang saham institusional sangat aktif dalam mengawasi perusahaan. Pemegang saham institusional bersungguh-sungguh untuk memantau, karena investor institusi mempercayakan para ahli untuk memonitor, dan investor institusional sering menginvestasikan uang dalam jumlah banyak.

Bursa Efek Indonesia mencatat pertumbuhan yang sangat besar pada perusahaan industri dasar dan kimia selama tahun 2018. Menurut BEI, sektor ini tumbuh hingga $21,17 \%$ year to date (Rahmawati, 2018). Tingginya petumbuhan sektor ini mengindikasikan makin tinggi pendapatan dan memicu beban pajak penghasilan yang besar (Richardson dkk., 2013). Oleh karena itu, penelitian ini bertujuan untuk menguji kembali faktor-faktor yang mempengaruhi praktik penghindaran pajak (tax avoidance) pada perusahaan sektor industri dasar dan kimia.

\section{KAJIAN LITERATUR DAN PENGEMBANGAN HIPOTESIS}

\section{Pengaruh Manajemen Laba terhadap Penghindaran Pajak (Tax Avoidance)}

Manajemen Laba diartikan sebagai respons manajemen perusahaan untuk mengintrevensi atau mempengaruhi informasi-informasi dalam laporan keuangan dengan tujuan untuk mengelabui stakeholder yang ingin mengetahui kinerja dan status perusahaan (Sulistyanto, 2008). Dari sisi lain 
penghindaran pajak menjadi kegiatan perencanaan pajak yang umum dilaksanakan dalam perusahanperusahaan besar yang terlibat dalam pengurangan tingkat pajak yang efektif (Hlaing, 2012). Sehingga dengan penghindaran pajak, pajak yang dibayarkan menjadi lebih rendah dari yang semestinya dibayarkan kepada negara.

Makin tinggi laba perusahaan maka akan makin tinggi pula laba bersih yang dihasilkan oleh perusahaan tersebut. Oleh karena itu beban pajak yang harus dibayarkan akan makin tinggi juga. Hal ini bisa membantu perusahaan dalam menerapkan praktik manajemen laba untuk mengurangi beban pajak agar dapat memperoleh laba yang makin tinggi. Berdasarkan pernyataan diatas, maka dikembangkan hipotesis sebagai berikut.

\section{$H_{1}$ : manajemen laba berpengaruh terhadap penghindaran pajak perusahaan}

\section{Pengaruh Leverage terhadap Penghindaran Pajak}

Dalam keuangan, leverage memiliki arti yang sama karena dapat meningkatkan tingkat keuntungan yang diharapkan. Dengan memperbanyak tingkatan rasio leverage maka akan berpengaruh tidak pasti dari tingkat keuntungan didapatkan makin tinggi, akan tetapi diwaktu yang sama hal ini dapat memperbesar jumlah keuntungan yang didapatkan (Syamsuddin, 2016). Istilah leverage digunakan untuk menunjukkan pemakaian utang sebagai cara untuk membiayai investasi. Perusahaan memanfaatkan rasio leverage memiliki tujuan untuk mendapatkan tingkat laba yang lebih banyak, hal tersebut dapat meningkatkan keuntungan bagi investor. Cara ini dapat dilakukan agar tidak menimbulkan beban bunga, sehingga tidak memicu terjadinya laba kena pajak.

Penelitian yang dilakukan oleh Adelina (2012) dan Prakosa (2014) menyimpulkan bahwa penambahan jumlah utang menyebabkan beban bunga yang harus dibayar oleh perusahaan akan bertambah. Makin tinggi nilai rasio leverage maka makin tinggi pula jumlah pendanaan dari utang pihak ketiga yang digunakan oleh perusahaan dan makin tinggi pula beban bunga yang muncul dari utang. Beban bunga yang makin tinggi akan memberikan dampak berkurangnya beban pajak perusahaan. Berdasarkan uraian diatas terdapat hipotesis sebagai berikut.

\section{$\mathrm{H}_{2}$ : leverage berpengaruh terhadap penghindaran pajak}

\section{Pengaruh Kepemilikan Institusional terhadap Penghindaran Pajak}

Kepemilikan Institusional mempunyai definisi penting dalam memantau manajemen karena ini akan mendorong kenaikan pengawasan yang maksimal. Makin tinggi kepemilikan institusonal maka makin tinggi tingkat inspeksi terhadap para manajer dapat meminimalisir perselisihan kepentingan antar manajemen sehingga masalah dengan keagenan berkurang, dan mengurangi kesempatan terbentuknya penghindaran pajak.

Setiap perusahaan memiliki kepentingan sendiri oleh karena itu perusahaan sebisa mungkin untuk mencegah terjadinya konflik antara pihak-pihak yang dapat menjatuhkan reputasi perusahaan, maka perlu adanya kepemilikan institusional untuk memantau pihak-pihak yang memiliki kepentingan yang berbeda (Winata, 2014). Penelitian yang dilakukan Rahmawati (2016) menyimpulkan bahwa kepemilikan instistusional berpengaruh negarif terhadap praktik penghindaran pajak. Maka, makin tinggi kepemilikan institusional diharapkan dapat meminimalisir praktik penghindaran pajak yang dilakukan oleh perusahaan. Oleh karena itu, rumusan hipotesis yang diuji dan diteliti adalah sebagai berikut.

\section{$\mathrm{H}_{3}$ : kepemilikan institusional berpengaruh terhadap penghindaran pajak}




\section{Pengaruh Dewan Komisaris terhadap Penghindaran Pajak}

Proporsi dewan komisaris independen yakni sesorang yang termasuk afiliasi anggota pemegang saham, direksi, anggota dewan komisaris, dan bebas atau tidak memiliki jabatan. Tugas komisaris independen pada dasarnya seperti anggota dewan komisaris lain, sebagi penasihat dan pengawas. Komisaris Independen bertindak sebagai perantara antara manajemen perusahaan dan direktur dalam mengambil keputusan (Ardyansyah, 2014).

Menurut Hidayati \& Fidiana (2017), komisaris independen dapat berfungsi efektif untuk melakukan deteksi dini terhadap adanya potensi penyimpangan ataupun kecurangan. Bentuk kefektifan peran komisaris independen salah satunya yaitu perusahaan bisa menjalankan kewajibannya secara utuh termasuk kewajiban perpajakannya. Oleh karena itu makin besar proporsi dewan komisaris independen diharapkan perusahaan tidak melakukan praktik penghindaran pajak. Maharani \& Suardana (2014) menyimpulkan bahwa komisaris independen berpengaruh negatif signifikan terhadap penghindaran pajak. Hal tersebut menunjukkan keberadaan dewan komisaris independen efektif dalam usaha mencegah praktik penghindaran pajak. Oleh karena itu, rumusan hipotesis yang diuji dalam penelitian ini adalah sebagai berikut.

$\mathrm{H}_{4}$ : proporsi dewan komisaris independen berpengaruh terhadap penghindaran pajak.

\section{Pengaruh Komite Audit terhadap Penghindaran Pajak}

Komite audit bertugas sebagai pengawas proses pembuatan laporan keuangan dan pengawasan internal, karena BEI mewajibkan semua emiten untuk membentuk dan memiliki komite audit yang diketuai oleh komisaris independen (Fadhilah \& Rahmi, 2014). Sesuai dengan surat edaran, komite audit dalam suatu perusahaan paling sedikit tiga orang. Keberadaan komite audit diharapkan dapat meningkatkan kualitas pengawasan internal.

Berdasarkan hasil penelitian Maharani \& Suardana (2014) dan Dewi \& Jati (2014) menunjukkan bahwa komite audit berpengaruh negatif signifikan terhadap penghindaran pajak. Menunjukkan makin tinggi keberadaan komite audit dalam perusahaan maka kemungkinanan memperkecil praktik penghindaran pajak yang dilakukan. Oleh karena itu, rumusan hipotesis yang diuji dalam penelitian ini adalah sebagai berikut.

\section{$\mathrm{H}_{4}$ : komite audit berpengaruh terhadap penghindaran pajak.}

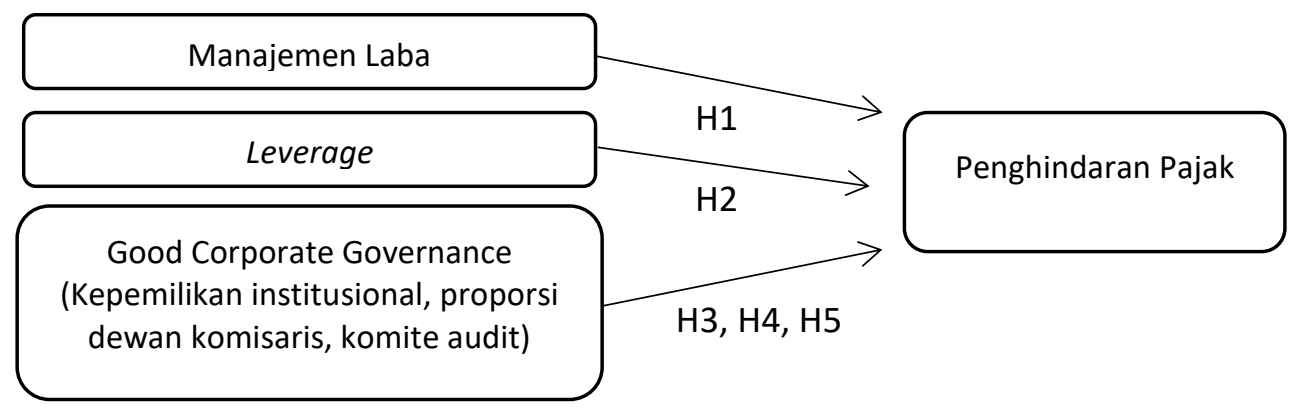

Gambar 1. Kerangka Berfikir 


\section{METODE PENELITIAN}

Penelitian ini adalah penelitian kuantitatif dengan sumber data berupa data sekunder, yaitu dari laporan tahunan perusahaan. Metode pengumpulan data yang digunakan adalah metode dokumentasi, yaitu dengan mengunduh laporan tahunan pada laman Bursa Efek Indonesia (BEI). Populasi penelitian ini adalah seluruh perusahaan industri dasar dan kimia yang terdaftar di BEl. Sampel penelitian dipilih menggunakan metode purposive sampling dengan kritera sebagai berikut: perusahaan kimia dasar yang terdaftar pada BEI pada periode 2015-2019; tidak melakukan delisting selama periode penelitian, dan yang memiliki laporan tahunan lengkap pada periode penelitian.

Variabel dependen dalam penelitian ini adalah penghindaran pajak yang diukur menggunakan rumus ETR (Effective Tax Rate).

$$
\text { Effective Tax Rate }=\frac{\text { Beban Pajak Penghasilan }}{\text { Pendapatan Sebelum Pajak }}
$$

Manajemen laba diukur menggunakan metode non-diskretioner yang diukur sebagai berikut.

$$
D A_{i t}=\frac{T A_{i t}}{T A_{i t-1}}-N D A_{i t}
$$

Dengan keterangan sebagai berikut: $D A_{i t}$ adalah discretionary accruals perusahaan i dalam periode tahun t; $N D A_{i t}$ adalah non discretionary accruals perushaaan i dalam periode tahun t; $T A C_{i t}$ adalah total accruals perusahaan i dalam periode t. Leverage diukur menggunakan debt equity ratio dengan membandingan total utang dengan total aset perusahaan sebagai berikut.

$$
D E R=\frac{\text { Total Hutang }}{\text { Total Aset }} \times 100 \%
$$

Kepemilikan institusional adalah kepemilikan yang hanya dimiliki oleh pemerintah, perusahaan asuransi, investor asing, dan bank, kecuali kepemilikan individual investor.

$$
\text { Kepemilikan Institusional }=\frac{\text { Jumlah Saham Institusional }}{\text { Jumlah Saham yang beredar }} \times 100 \%
$$

Proporsi dewan komisaris independen yakni sesorang yang termasuk afiliasi anggota pemegang saham, direksi, anggota dewan, dan bebas atau tidak memiliki kedudukan.

$$
\text { Proporsi Dewan Komisaris Independen }=\frac{\Sigma \text { Komisaris Independen }}{\Sigma \text { Dewan Komisaris }}
$$

Komite audit diukur sebanyak jumlah anggota dewan komite audit yang jumlahnya cenderung sedikit. Komite audit pada umumnya dipilih oleh dewan komisaris independen. Metode analisis data menggunakan analisis regresi berganda dengan formula regresi berganda sebagai berikut.

$$
E T R=\alpha+\beta 1 \mathrm{X} 1+\beta 2 \mathrm{X} 2+\beta 3 \mathrm{X} 3+\beta 4 \mathrm{X} 4+\beta 5 \mathrm{X} 5+\mathrm{e}
$$




\section{HASIL DAN PEMBAHASAN}

\section{Uji Statistik Deskriptif}

Berikut adalah hasil uji deskriptif yang menunjukkan gambaran objek penelitian.

Tabel 1. Deskripsi Variabel Penelitian

\begin{tabular}{lrrrrr}
\hline & N & Minimum & Maksimum & Mean & Std. Deviation \\
\hline DA & 60 & $-0,010$ & 0,010 & 0,001 & 0,004 \\
DER & 60 & 0,100 & 0,960 & 0,386 & 0,216 \\
DKI & 60 & 0,250 & 0,600 & 0,448 & 0,124 \\
KI & 60 & 0,464 & 0,924 & 0,707 & 0,138 \\
KA & 60 & 3 & 5 & 3,320 & 0,676 \\
ETR & 60 & 0,120 & 0,340 & 0,225 & 0,051 \\
\hline
\end{tabular}

Nilai DER menunjukkan besarnya proporsi utang terhadap aset yang dimiliki perusahaan. Pada objek penelitian menunjukkan nilai rata-rata $38,7 \%$ yang berarti rata-rata rasio utang terhadap aset adalah $38,7 \%$. Namun, nilai maksimum yang cukup besar, yaitu $96 \%$ yang berarti rasio utangnya adalah $96 \%$ dari aset perusahaan. Rata-rata perusahaan memiliki jumlah komisaris independen sebesar $44,8 \%$ dari seluruh dewan komisaris.

\section{Uji Normalitas}

Uji normalitas bertujuan untuk menguji apakah dalam model regresi, variabel pengganggu atau residual memiliki distribusi normal. Untuk menguji asumsi normalitas digunakan grafik Normal P-P Plot dan uji Kolmogorov-Smirnov.

Tabel 2. Hasil Uji Normalitas

\begin{tabular}{llr}
\hline & & Unstandardized Residual \\
\hline $\mathrm{N}$ & & 60 \\
Normal & Mean & 0,000 \\
Parameters ${ }^{a, b}$ & Std. Deviation & 0,043 \\
& Absolute & 0,055 \\
Most Extreme & Positive & 0,049 \\
Differences & Negative & $-0,055$ \\
Kolmogorov-Smirnov Z & 0,429 \\
Asymp. Sig. (2-tailed) & 0,993 \\
\hline
\end{tabular}

Hasil uji normalitas residual menggunakan uji Kolmogorov-Smirnov diperoleh nilai signifikansi sebesar 0,993 sehingga nilai signifikansi lebih dari 0,050 $(p>0,050)$ artinya residual mengikuti distribusi normal dan asumsi normalitas terpenuhi.

\section{Analisis Regresi Linier Berganda}

Analisis regresi linier berganda bertujuan untuk memperoleh gambaran mengenai pengaruh antara variabel bebas terhadap variabel terikat baik secara keseluruhan (simultan) maupun secara individu (parsial). Berikut disajikan hasil regresi linier berganda antara manajemen laba (DA), leverage (DER), 
dewan komisaris independen (DKI), kepemilikan institusional (KI), dan komite audit (KA) terhadap penghindaran pajak (ETR).

Tabel 6. Hasil Regresi Linier Berganda

\begin{tabular}{|c|c|c|c|c|c|c|}
\hline & \multirow[t]{2}{*}{ Model } & \multicolumn{2}{|c|}{$\begin{array}{l}\text { Unstandardized } \\
\text { Coefficients }\end{array}$} & \multirow{2}{*}{$\begin{array}{c}\begin{array}{c}\text { Standardized } \\
\text { Coefficients }\end{array} \\
\text { Beta } \\
\end{array}$} & \multirow[t]{2}{*}{$\mathbf{t}$} & \multirow[t]{2}{*}{ Sig. } \\
\hline & & B & Std. Error & & & \\
\hline \multirow{6}{*}{1} & (Constant) & 0,357 & 0,060 & & 5,948 & 0,000 \\
\hline & DA & $-3,075$ & 1,680 & $-0,226$ & $-1,830$ & 0,073 \\
\hline & DER & $-0,066$ & 0,032 & $-0,275$ & $-2,042$ & 0,046 \\
\hline & DKI & $-0,010$ & 0,055 & $-0,024$ & $-0,180$ & 0,858 \\
\hline & $\mathrm{KI}$ & 0,000 & 0,001 & $-0,065$ & $-0,440$ & 0,662 \\
\hline & KA & $-0,024$ & 0,012 & $-0,321$ & $-2,040$ & 0,046 \\
\hline
\end{tabular}

Hasil persamaan regresi linier berganda antara variabel manajemen laba (DA), leverage (DER), dewan komisaris independen (DKI), kepemilikan institusional (KI), dan komite audit (KA) terhadap penghindaran pajak (ETR) disajikan sebagai berikut.

$$
\begin{aligned}
& E T R=\alpha+\beta 1 \mathrm{X} 1+\beta 2 \mathrm{X} 2+\beta 3 \mathrm{X} 3+\beta 4 \mathrm{X} 4+\beta 5 \mathrm{X} 5+\mathrm{e} \\
& \mathrm{ETR}=0,357-3,075 \mathrm{X} 1-0,066 \mathrm{X} 2-0,011 \mathrm{X} 3+0,000 \mathrm{X} 4-0,024 \mathrm{X} 5+\mathrm{e}
\end{aligned}
$$

\section{Koefisien Determinasi $\left(\mathbf{R}^{2}\right)$}

Koefisien determinasi menjelaskan seberapa besar kemampuan variabel bebas dalam menerangkan variasi variabel terikat. Nilai koefisien determinasi yang makin besar atau mendekati satu menunjukkan makin besar kemampuan variabel bebas dalam menerangkan variasi variabel terikat. Berikut disajikan hasil koefisien determinasi dengan menggunakan $\mathrm{R}^{2}$.

Tabel 8. Hasil Koefisien Determinasi

\begin{tabular}{ccccc}
\hline Model & $\mathbf{R}$ & $\begin{array}{c}\boldsymbol{R} \\
\text { Square }\end{array}$ & $\begin{array}{c}\text { Adjusted } \boldsymbol{R} \\
\text { Square }\end{array}$ & $\begin{array}{c}\text { Std. Error Of The } \\
\text { Estimate }\end{array}$ \\
\hline 1 & 0,551 & 0,303 & 0,239 & 0,045 \\
\hline
\end{tabular}

Hasil koefisien determinasi didapatkan nilai $R$ Square sebesar 0,303 artinya bahwa besar pengaruh terhadap variabel penghindaran pajak (ETR) yang dijelaskan oleh variabel manajemen laba (DA), leverage (DER), dewan komisaris independen (DKI), kepemilikan institusional (KI), dan komite audit (KA) adalah sebesar $30,30 \%$, sedangkan sisanya dijelaskan oleh faktor lain.

\section{Uji Parsial (Uji-t)}

Uji t atau uji parsial menjelaskan ada tidaknya pengaruh antara variabel bebas manajemen laba (DA), leverage (DER), dewan komisaris independen (DKI), kepemilikan institusional (KI), dan komite audit (KA) terhadap variabel terikat penghindaran pajak (ETR) secara individu (parsial). Berikut disajikan hasil pengujian pengaruh secara parsial dengan menggunakan uji t. 
Yona Yuniar: Fenomena Penghindaran Pajak ...

Tabel 9. Hasil Uji Parsial

\begin{tabular}{rlrll}
\hline \multicolumn{1}{c}{ Model } & \multicolumn{1}{c}{ t } & \multicolumn{1}{l}{ Sig. } & \multicolumn{1}{c}{ Kesimpulan } \\
\hline \multirow{4}{*}{1} & (Constant) & 5,948 & 0,000 & \\
& DA & $-1,830$ & 0,073 & Tidak berpengaruh \\
& DER & $-2,042$ & 0,046 & Berpengaruh \\
& DKI & $-0,180$ & 0,858 & Tidak berpengaruh \\
& KI & $-0,440$ & 0,662 & Tidak berpengaruh \\
& KA & $-2,040$ & 0,046 & Berpengaruh \\
\hline
\end{tabular}

Uji parsial antara variabel manajemen laba (DA) terhadap variabel penghindaran pajak (ETR) didapatkan nilai $t$ hitung sebesar 1,830 kurang dari nilai t tabel sebesar 2,005 atau nilai signifikansi sebesar 0,073 lebih dari nilai alpha sebesar 0,050 sehingga tidak terdapat pengaruh signifikan antara variabel manajemen laba (DA) terhadap variabel penghindaran pajak (ETR). Uji parsial antara variabel leverage (DER) terhadap variabel penghindaran pajak (ETR) didapatkan nilai t hitung sebesar 2,042 lebih dari nilai t tabel 2,005 atau nilai signifikansi sebesar 0,046 kurang dari nilai alpha sebesar 0,050 sehingga terdapat pengaruh signifikan antara variabel leverage (DER) terhadap variabel penghindaran pajak (ETR).

Uji parsial antara variabel dewan komisaris independen (DKI) terhadap variabel penghindaran pajak (ETR) didapatkan nilai t hitung sebesar 0,180 yang kurang dari t tabel sebesar 2,005 atau nilai signifikansi sebesar 0,858 lebih dari alpha sebesar 0,050 sehingga tidak terdapat pengaruh signifikan antara variabel dewan komisaris independen (DKI) terhadap variabel penghindaran pajak (ETR). Uji parsial antara variabel kepemilikan institusional (KI) terhadap variabel penghindaran pajak (ETR) dengan nilai t hitung sebesar 0,440 kurang dari t tabel $(2,005)$ atau nilai signifikansi sebesar 0,662 lebih dari alpha 0,050 sehingga tidak terdapat pengaruh antara variabel kepemilikan institusional (KI) terhadap variabel penghindaran pajak (ETR). Uji parsial antara variabel komite audit (KA) terhadap variabel penghindaran pajak (ETR) didapatkan nilai t hitung 2,040 lebih dari t tabel 2,005 atau nilai signifikansi 0,046 kurang dari alpha sebesar 0,050 sehingga terdapat pengaruh signifikan antara variabel komite audit (KA) terhadap variabel penghindaran pajak (ETR).

Pengaruh Manajemen Laba, Leverage, dan Good Corporate Governance dengan Penghindaran Pajak Hasil penelitian menunjukkan bahwa manajemen laba tidak berpengaruh signifikan terhadap penghindaran pajak, maka $\mathrm{H} 1$ ditolak. Hasil penelitian ini konsisten dengan penelitian yang dilakukan oleh Diatmika \& Sukartha (2019) tentang pengaruh manajemen laba pada agresivitas pajak dan implikasinya terhadap nilai perusahaan bahwa manajemen laba tidak berpengharuh pada penghindaran pajak perusahaan. Hal ini menunjukkan bahwa jika perusahaan melakukan manajemen laba, berarti bukan untuk tujuan mengurangi pajak. Manajemen laba dilakukan salah satunya untuk menyajikan nilai laba yang stabil dari waktu ke waktu yang ditujukan untuk menarik investor bukan untuk agresivitas pajak.

Hasil penelitian menunjukkan bahwa leverage berpengaruh terhadap penghindaran pajak. Hasil penelitian ini mendukung penelitian yang dilakukan oleh Putri \& Putra (2017) yang menyatakan leverage berpengaruh negatif dan signifikan terhadap penghindaran pajak. Hal ini menunjukkan makin tinggi nilai dari rasio leverage berarti makin tinggi jumlah pendanaan dari pihak ketiga dalam bentuk utang sehingga akan meningkatkan biaya bunga dari utang. Tingginya biaya bungan akan mengurangi laba perusahaan sebelum pajak yang berarti juga mengurangi beban pajak perusahaan. Dapat disimpulkan bahwa kebijakan perusahaan untuk menggunakan utang (meningkatkan leverage) dapat digunakan untuk penghematan pajak dengan memperoleh insentif berupa beban bunga yang akan menjadi 
pengurang penghasilan kena pajak. Beban bunga yang bisa dikurangi laba adalah beban yang timbul untuk memberikan peminjaman kepada pihak ketiga. Rasio leverage merupakan rasio yang menunjukkan bahwa besarnya modal dari pihak luar yang digunakan perusahaan untuk membiayai kegiatan operasionlanya. Husnaini dkk. (2013) menyatakan bahwa kebijakan pendanaan suatu perusahaan akan mempengaruhi tariff pajak efektif hal ini di karenakan pajak memiliki perlakuan yang berbeda terkait dengan struktur modal. Perusahaan tidak hanya mendapatkan sumber dana yang berasal dari modal sendiri akan tetapi berasal dari utang. Dengan sumber dana yang berasal dari utang dapat mengakibatkan muncul beban tetap yaitu beban bunga.

Hasil penelitian ini menunjukkan kepemilikan institusional dan dewan komisaris independen tidak mempengaruhi tindakan penghindaran pajak. Secara ideal, adanya kepemilikan institusional (perusahaan efek, perusahaan asuransi, perbankan, perusahaan investasi, dana pensiun) dan dewan komisaris independen dapat mendorong peningkatan pengawasan terhadap kinerja manajemen. Pemilik institusional berdasarkan besar dan hak suara yang dimiliki, dapat memaksa manajer untuk berfokus pada kinerja ekonomi dan menghindari peluang untuk perilaku mementingkan diri sendiri. Demikian juga dengan adanya komisaris independen yang berwenang melakukan pengawasan terhadap kinerja manajemen. Namun demikian, hasil penelitian menunjukkan bahwa peran dari adanya kepemilikan institusional dan komisaris independen tidak mempengaruhi kinerja manajemen. Hal tersebut dikarenakan keberadaan komisaris independen hanya sebagai pemenuh kebutuhan terhadap kepatuhan peraturan, selain itu peran pemegang saham mayoritas dalam perusahaan masih sangat kuat sehingga kinerja dewan komisaris tidak meningkat.

Hasil penelitian menunjukkan bahwa komite audit berpengaruh negatif dan signifikan terhadap penghindaran pajak. Dalam penelitian ini mendukung penelitian yang dilakukan oleh Dewi \& Jati (2014) menyatakan bahwa komite audit berpengaruh negatif dan signifikan terhadap penghindaran pajak. Hal ini menunjukkan bahwa makin banyak jumlah komite audit pada perusahaan maka semkain kecil tingkat agresivitas pajak. Keberadaan dalam komite audit sangat dibutuhkan dalam perusahaan agar dapat membantu dewan komisaris dalam meningkatkan pengawasan terhadap manajemen perusahaan, sehingga dapat menjadi usaha perbaikan terhadap tata cara pengelolaan perusahaan. Dengan adanya komite audit diharapkan perusahaan akan lebih bertanggung jawab dan terbuka dalam menyajikan laporan keuangan. Komite audit dapat mengawasi mekanisme pelaporan keuangan sehingga dapat meningkatkan kualitas informasi bagi para stakeholders. Keberadaaan komite audit yang mempunyai tugas untuk melakukan pengawasan dan pengevaluasian terhadap kinerja operasional agar dapat berjalan dengan baik, dalam mekanisme tata kelola perusahaan komite audit berperan aktif dalam penetapan kebijakan terkait dengan kebijakan beban pajak yang memiliki hubungan erat terhadap aktifitas penghindaran pajak.

\section{KESIMPULAN}

Hasil penelitian menunjukkan bahwa manajemen laba, dewan komisaris indepeden, dan kepemilikan institusional tidak mempengaruhi tindakan penghindaran pajak. Keberadaan komite audit dan tingkat leverage mempengaruhi tindakan penghindaran pajak. Hal ini mengindikasikan bahwa dalam melakukan manajemen laba, perusahaan bukan bertujuan pada tindakan penghindaran pajak melainkan untuk menarik minat investor dengan menyajikan laba yang stabil. Selain itu, hasil peneitian ini mengindikasikan bahwa adanya dewan komisaris independen dan kepemilikan institusional tidak dapat dapat mencegah terjadinya praktik penghindaran pajak yang menunjukkan tidak efektifnya peran dewan komisaris independen. Bagi perusahaan hendaknya melakukan evaluasi manajemen atas pembayaran pajak untuk dilakukannya efisiensi perpajakan dengan menggunakan tax avoidance tanpa masuk ke ranah pelanggaran peraturan perpajakan. Perusahaan sebaiknya lebih meningkatkan kinerja dewan 
komisaris khususnya dewan komisaris independen. Perusahaan harus memperhatikan level kompetisi, keahlian, dana pengalaman dari setiap anggota dewan agar terhindar dari tindakan kecurangan khususnya penghindaran pajak diantaranya dengan menambah jumlah dewan komisaris independen yang tidak terafiliasi dengan perusahaan dan memiliki pengetahuan lebih mengenai perpajakan perusahaan serta memiliki tingkat independensi yang tinggi.

\section{DAFTAR PUSTAKA}

Adelina. (2012). Pengaruh Karekteristik Perusahaan dan Reformasi Perpajakan terhadap Penghindaran Pajak. Universitas Indonesia.

Ardiansyah, M. (2014). Pengaruh Corporate Governance, Leverage Dan Profitabilitas Terhadap Manajemen Laba. Universitas Maritim Raja Ali Haji.

Budiman, J., \& Setiyono, M. (2012). Pengaruh Karakteristik Eksekutif terhadap Penghindaran Pajak (Tax Avoidance). Universitas Gadjah Mada.

Dewi, N. N. K., \& Jati, I. K. (2014). Pengaruh Karakter Eksekutif, Karakteristik Perusahaan, dan Dimensi Tata Kelola Perusahaan yang Baik pada Tax Avoidance. E-Journal Akutansi Universitas Udayana, 6 (2), 249-260.

Dewinta, I. A. R., \& Setiawan, P. E. (2016). Pengaruh Ukuran Perusahaan, Profitabilitas, Leverage, dan Pertumbuhan Penjualan terhadap Tax Avoidance. E-Jurnal Akuntansi Universitas Udayana, 14(3), 1584-1613.

Diatmika, D. \& Sukartha, I. M. (2019). Pengaruh Manajemen Laba Pada Agresivitas Pajak dan Implikasinya Terhadap Nilai Perusahaan. E-Jurnal Akuntansi Universitas Udayana, 26(1), 591-621. https://doi.org/10.24843/EJA.2019.v26.i01.

Fadhilah, \& Rahmi. (2014). Pengaruh Good Corporate Governance Terhadap Tax Avoidance (Studi Empiris pada Perushaan Manufaktur yang Terdaftar Di Bursa Efek Indonesia 2009-2011). Jurnal Akuntansi Universitas Negeri Padang, 2(1), 1-20.

Hidayati, \& Fidiana. (2017). Pengaruh Corporate Sosial Responsibility dan Good Corporate Governance terhadap Penghindaran Pajak. Jurnal IImiah dan Riset Akuntansi 6(3), 1053-1070.

Hlaing, K.P. (2012). Organizational Architecture of Multinationals and Tax Aggressiveness. Canada: University of Waterloo.

Husnaini, Maesarah, \& Atikah. (2013, Desember 2). Pengaruh Karakteristik Perusahaan dan Corporate Social Responsibility terhadap Penghindaran (Paper Presentation). Konferensi Regional Akuntansi (KRA) II Tahun 2015.

Maharani, I Gusti, C. A., \& Suardana. (2014). Pengaruh Corporate Governance, Profitabilitas, dan Karakteristik Eksekutif terhadap Tax Avoidance Perusahaan Manufaktur. E-Jurnal Akuntansi Universitas Udayana, 9(2), 525-539.

Marfiah, D., \& Syam, F. (2016). Pengaruh Corporate Governance Dan Leverage Terhadap Tax Avoidance Pada Perusahaan Manufaktur Yang Terdaftar Di Bursa Efek Indonesia (BEI) Tahun 2011-2015. Jurnal Ilmiah Mahasiswa Ekonomi Akuntansi Unsyiah (JIMEKA), 1(2), 91-103.

Prakosa. (2014). Pengaruh Profitabilitas, Kepemilikan Keluarga dan Corporate Governance Terhadap Penghindaran Pajak di Indonesia. Proceeding Simposium Nasional Akuntansi XVII, 1-27.

Putri, V. R., \& Putra, B. I. (2017). Pengaruh Leverage, Profitability, Ukuran Perusahaan Dan Proporsi Kepemilikan Institusional Terhadap Tax Avoidance. Daya Saing: Jurnal Ekonomi Manajemen Sumber Daya, 19(1), 1-11. https://doi.org/10.23917/dayasaing.v19i1.5100.

Rahmawati, A., Endang, M. W., \& Agusti, R. R. (2016). Pengaruh Pengungkapan Corporate Social Responsibility dan Corporate Governance terhadap Tax Avoidance. Jurnal Perpajakan (JEJAK), 1(10), 1-9. 
Rahmawati, W. (2018, Desember 23). Naik Tertinggi, Saham Sektor Industri Dasar Dan Kimia Terimbas Sentimen Positif. Kontan. https://investasi.kontan.co.id/news/naik-tertinggi-saham-sektorindustri-dasar-dan-kimia-terimbas-sentimen-positif.

Richardson, G., Taylor, G., \& Lanis, R. (2013). The Impact Of Board Of Director Oversight Characteristics On Corporate Tax Aggressiveness: An Empirical analysis. Journal Of Accounting And Public Policy, 32(3), 68-88. https://doi/org/10.1016/j.jaccpubpol.2013.02.004

Sulistyanto, H. S. (2008). Manajemen Laba : Teori dan Empiris. Jakarta: PT Grasindo.

Surbakti, T. A. V. (2012). Pengaruh Karakteristik Perusahaan dan Reformasi Perpajakan Terhadap Penghindaran Pajak. Universitas Indonesia.

Syamsuddin, L. (2016). Manajemen Keuangan Perusahaan. Jakarta: Rajawali.

Winata, F. (2014). Pengaruh Corporate Governance terhadap Tax Avoidance. Tax \& Accounting Review, $4(1), 1-11$.

Yoehana, M. (2013). Analisis Pengaruh Corporate Social Responsibility terhadap Agresivitas Pajak. Universitas Diponegoro Semarang. 
